\title{
List of boxes, figures and tables
}

\section{Boxes}

2.1 Premià de Mar 40

2.2 Badalona 44

\section{Figures}

2.1 Conflicts around mosques and oratories

2.2 Distribution of Islamic places of worship in Catalonia, by comarca (geographical administrative units) and protests against the opening of places of worship, 2001-06

5.1 Debate on voting rights

6.1 The Spanish identity issue

6.2 The historical context of diversity-related Spain

6.3 The legal framework affecting diversity management

6.4 The Spanish framework related to diversity issues

\section{Tables}

2.1 Conflicts and challenges of immigration-related diversity in Spain

2.2 Overview of Muslim population, registered Islamic communities, principal mosques and cases of opposition to the building of mosques or opening of oratories, by autonomous community

3.1 Indicators for analysis

3.2 Levels of analysis and data sources

4.1 Basic characteristics of foreign workers (EU, TCNs and total) affiliated with the Social Security System

5.1 Main periods of the voting rights debate

5.2 Basic arguments of conservative/progressive positions 